\title{
Qualitative and Quantitative Analysis of AgNORs in FNAC Smears of Palpable Breast Lumps
}

\author{
Tamanna Binta Hasan ${ }^{1 *}$ \\ Shoibul Karim ${ }^{2}$ \\ Mohammad Ismail Hossain ${ }^{3}$ \\ Md Quamrul Hassan ${ }^{4}$ \\ Sayeda Nasreen ${ }^{3}$ \\ Pradip Bhattacharjee ${ }^{3}$ \\ Md Zillur Rahman ${ }^{3}$
}

\author{
${ }^{1}$ Department of Pathology \\ University of Science and Technology Chittagong (USTC) \\ Chittagong, Bangladesh. \\ ${ }^{2}$ Department of Surgery \\ Ibrahim lqbal Memorial Hospital \& \\ Medical College (BGC Trust) \\ Chittagong, Bangladesh. \\ ${ }^{3}$ Department of Pathology \\ Chittagong Medical College \\ Chittagong, Bangladesh. \\ ${ }^{4}$ Department of Pathology \\ Cox'sBazar Medical College \\ Cox'sBazar, Bangladesh.
}

*Correspondence to:

Dr. Tamanna Binta Hasan Assistant Professor

Department of Pathology

University of Science and Technology Chittagong (USTC)

Chittagong, Bangladesh

Mobile: +880 01819615210

Email: tui8bd@yahoo.com.

www.banglajol.info/index.php/CMOSHMC

\begin{abstract}
Background: The study aimed to evaluate the efficacy of AgNORs on FNAC smears of breast lesion. Methods: FNAC were done in 200 female patients of breast lump consecutively, Papanicolau and AgNOR staining was done in all 200 cases of FNA smears.Among them biopsy and histopathology were done in 99 cases. The findings of FNAC and AgNOR analysis were compared to histopathological findings. Results: By FNAC, 53 (26.5\%) cases were non-neoplastic benign, 89(44.5\%) cases were benign neoplasm, 07 (3.5\%) cases were atypical ductal hyperplasia and $51(25.5 \%)$ cases were malignant (Duct cell carcinoma).Among them histopathology was done in 99 cases. Out of 40 FNAC malignant cases, histopathologically all were proved malignant. Out of 42 benign cases, 1 was found malignant. 4 atypical ductal hyperplasia were also diagnosed as malignant histopathologically. True positive cases are 40, True negative cases are 36 , false positive are nil (0), and false negative is 01 . The sensitivity is $97.56 \%$, specificity is $100 \%$, positive predictive value is $100 \%$, Negative predictive value is $97.3 \%$, and accuracy is $98.7 \%$. AgNOR impression were analysed in 99 histopathologically confirmed cases. The results showed benign impression in 50 cases and malignant impression in 48 cases. 01 histopathologically malignant case was impressed as benign by AgNOR and 01 as suspicious which may be included as malignant by AgNOR impression. 2 histopathologically benign cases showed higher proliferative activities and counted as malignant. True positive cases are 46 , True negative 49 , false positive is 02 and false negative is 01 . The sensitivity is $97.87 \%$, Specificity $96.07 \%$, PPV $95.83 \%$, NPV 98\%, Overall accuracy is $96.93 \%$. Conclusion: The efficacy of FNAC and AgNOR analysis in the diagnosis of breast lesion was found more or less similar and mild over lapping.
\end{abstract}

Key words: Papanicolau; AgNORs; FNAC; Histopathology.

\section{INTRODUCTION}

Breast cancer is the top most cancer in women both in the developed and the developing world. Breast cancer survival rates vary greatly worldwide, ranging from $80 \%$ or over in developed countries, around $60 \%$ in middle-income countries and below $40 \%$ in low income countries. The low survival rates in less developed countries can be explained mainly by the lack of early detection programmes, resulting in a high proportion of women presenting with late-stage disease, as well as by the lack of adequate diagnosis and overall management facilities ${ }^{1}$. 
The mitotic rate is an important characteristic of malignant tumors. A high mitotic rate is common in malignant neoplasm. In addition to the ability to separate benign from malignant tumors based on their mitotic activity, the number of mitosis within a given tumor provides a rough indication on the rate of tumor proliferation and its diagnosis ${ }^{2,3}$.

The number of Nucleolar Organizer Regions (NORs) has been considered to reflect the proliferating activity of cells and to serve as an indicator of the malignancy level of tumour ${ }^{4}$. Their frequency within the nuclei is significantly higher in malignant cells than in normal, reactive or benign neoplastic cells $\mathrm{s}^{5,6,7}$.

NORs are loops of DNA in the human genome that have been associated with protein synthesis and ribosomal activity and are located in the short arm of the acrocentric chromosomes 13, 14, 15,21 and $22^{8,9,10}$.

These regions can be easily identified by light microscopy as discrete black dots after the application of silver stain, known as 'Argyrophilic Nucleolar Organizer Regions' (AgNORs) ${ }^{11}$.

Initially used as a parameter for the diagnosis of malignancy, the AgNOR parameter was found to be also useful for assessing the prognosis of cancer diseases ${ }^{12}$.

AgNOR count is a reproducible simple, efficient and inexpensive method, which can be used as an adjunct to routine $\mathrm{H} \& \mathrm{E}$ staining. The staining technique is a relatively simple and rapid one ${ }^{12,13}$.

Fine Needle Aspiration Cytology (FNAC) is now an integral part of the pre-operative investigation and therapeutic protocol of breast lesions ${ }^{7}$. FNAC has an advantage of being an immediate and excellent method for on-site examination and one-stop diagnosis at breast outpatient clinics. Since the majority of patients have benign disease, they benefit from rapid diagnosis and discharge from the clinic ${ }^{14}$. Mastectomies can be prevented by early diagnosis and open biopsies can be reduced ${ }^{15}$. However, from time to time, cytological picture may be equivocal or inconclusive ${ }^{8}$. The clinical use of FNAC has been questioned because of the variability in results reported. The use of Papanicolaou staining alone generates false-negative and false-positive results and the diagnostic accuracy is approximately $90 \%{ }^{16}$. False negativity of FNAC was also reported by Mendoza et $\mathrm{al}^{17}$. Addition of AgNORs analysis on FNA smear will definitely strengthen the accuracy of FNAC of breast in differentiating reactive, benign and malignant tumours of the breast. Although, the number of AgNORs is indicator of proliferative index, the addition of the measurement of size and area of dispersion gives improved diagnostic and prognostic specificity ${ }^{18}$.

No AgNOR study of breast lesions has been done so far in our country. This study was done in a view of evaluating the role of AgNORs analysis in FNA smear of breast lesions.

\section{MATERIALS AND METHODS}

It is a cross sectional descriptive study carried out in the Department of Pathology, Chittagong Medical College (CMC), Chittagong, during the period of one year from July 2013 to June 2014.200 Consecutive female patients, irrespective of their age, presenting with clinically palpable breast lumps attending in the Department of Pathology, CMC, referred from $\mathrm{CMCH}$ (Chittagong Medical College Hospital) and other hospitals and clinics or individual physicians of Chittagong were included in the study.

Informed written consent was taken from all the patients, included in this study, after full explanation of nature, purpose and potential risks of the study in the local language.

A brief Clinical history was taken from each patient and was recorded in a preformed questionnare proforma. Each patient was examined thoroughly and informations were recorded in details in all cases.

The patients presenting with palpable breast lump were undergone FNA in the FNAC lab of the Department of Pathology, CMC, Chittagong. At least four smears were prepared in each case, out of them two were immediately fixed in $95 \%$ alcohol for Papanicolau stain and two of them air dried followed by fixation in $95 \%$ alcohol for AgNOR stain. Two alcohol fixed smear were stained by Papanicolaou method.AgNOR staining were performed by using silver nitrate, gelatin and formic acid on air-dried, alcohol-fixed FNA smears ${ }^{19}$.

Excision biopsy was done from the cytologically diagnosed malignant cases and from cases, where excisions were indicated clinically and histopathological specimen was collected in these cases. The biopsy specimens, after processing $\&$ sections, blocks were prepared and slides were made and stained by Haematoxilin \& Eosin (H\&E).

\section{Examinations of the stained smear and sections}

i) Pap stained smear: Smears stained by Papanicolau were examined in light microscope. The cellularity and the morphological details were thoroughly studied to reach a diagnosis regarding the type of lesions.

ii) AgNOR stained smear: AgNOR stained smear were examined under light microscope using oil immersion lens with magnification of $100 \mathrm{x}$ and 100 randomly selected duct epithelial cells were studied for AgNOR count, size and dispersion.

\section{AgNOR count (mAgNOR)}

The NORs were seen as clear black dots in the nuclei. AgNOR dots present in cluster form in the nuclei were considered as one. The count was the mean number of AgNORs in 100 tumour nuclei (mAgNOR). 


\section{AgNOR size}

The grading of size variation was performed according to method used by Hossain et al and Khan et al ${ }^{19,20}$. Scores of distribution are given below:

0 : More or less uniform in size

$1+$ : Two different sizes

2+: More than two different sizes (But not those of 3+)

$3+$ : Including all sizes \& grade

\section{Proliferative AgNOR (pAgNOR)}

AgNOR proliferative index $(\mathrm{pAgNOR})=$ percentage of cells with 5 or more AgNOR dots. pAgNOR more than $8 \%$ was considered to display high proliferative activity. Malignant lesions show high proliferative activity. We considered $<8$ for benign lesions, 8-11 for suspicious lesions and $>11$ for malignant lesions Hossain et $\mathrm{al}^{19}$.

$\begin{array}{llll}\text { Parameter } & \text { Benign } & \text { Suspicious } & \text { Malignant } \\ \text { mAgNOR } & \text { Variable, } & \text { Variable, } & \text { Variable, } \\ & \text { but usually }<3 & \text { usually }>3 & \text { usually }>3 \\ \text { pAgNOR } & <8 \% & 8-11 \% & >11 \% \\ \text { Size grade } & 0-1+ & 2+-3+\text {, variable } & 2+-3+\text {, variable }\end{array}$

2 of the 3 parameter were taken to decide diagnosis and confirmed by histopathology.

iii) $\boldsymbol{H} \& \boldsymbol{E}$ stained sections: The stained sections were examined in the light microscope to get a definite diagnosis of the lesions and its type.

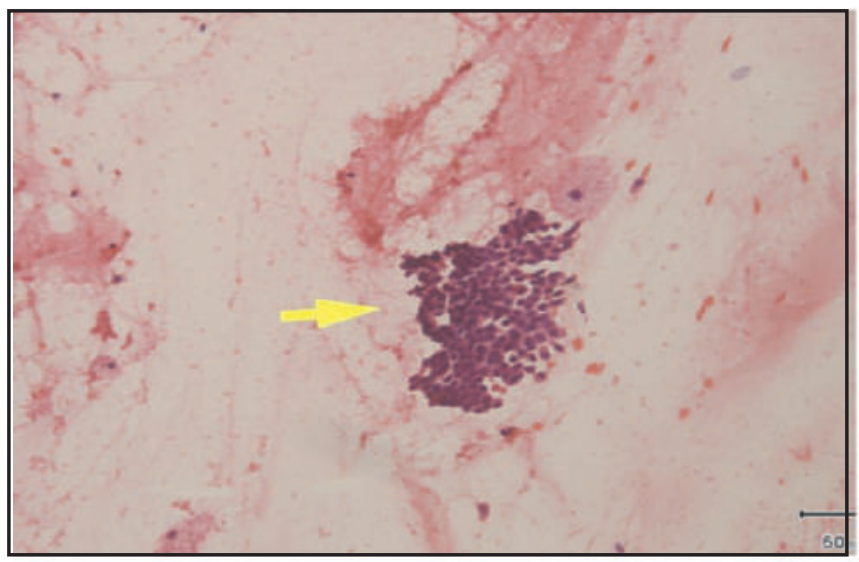

Figure 1 : Fibrocystic Change 100 X (Pap stain)FNA smear.

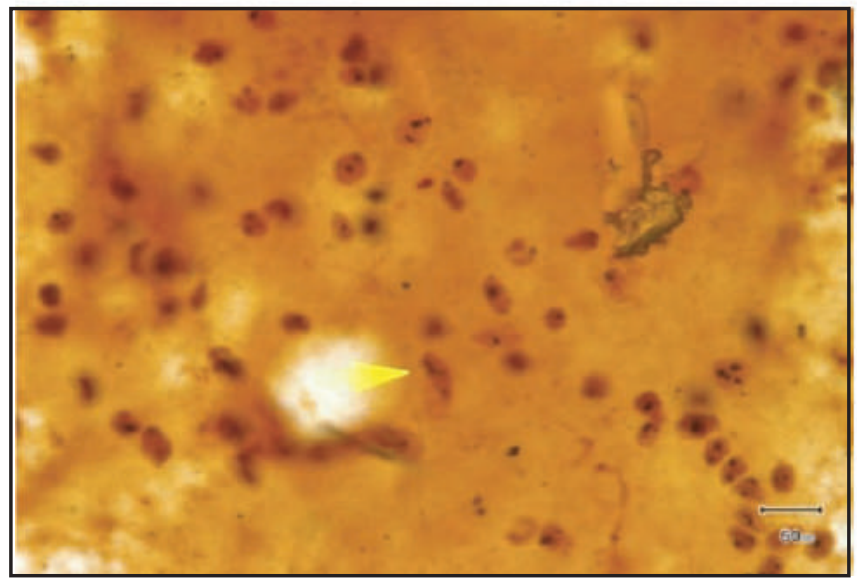

Figure 2 : Fibrocystic Change $1000 \mathrm{X}$ (AgNOR stain).

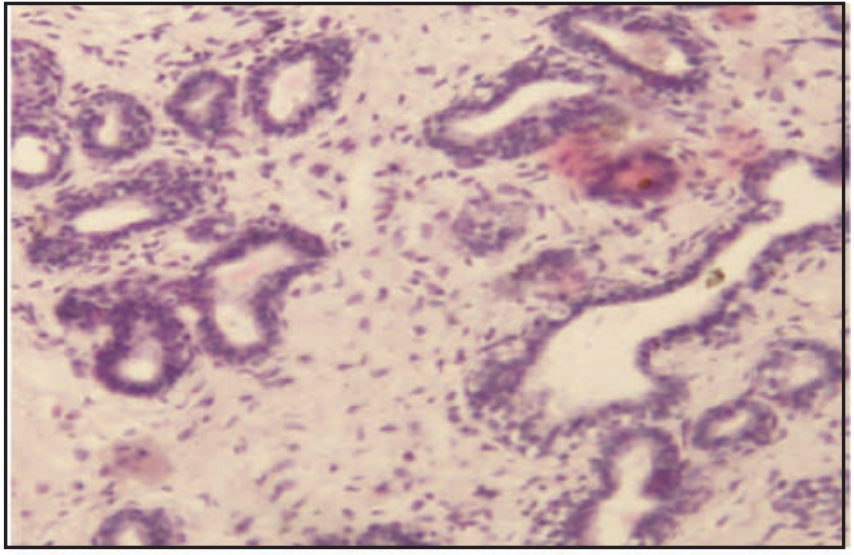

Figure 3 : Fibrocystic Change $400 \mathrm{X}$ (H \& E stain) Histopathology section.

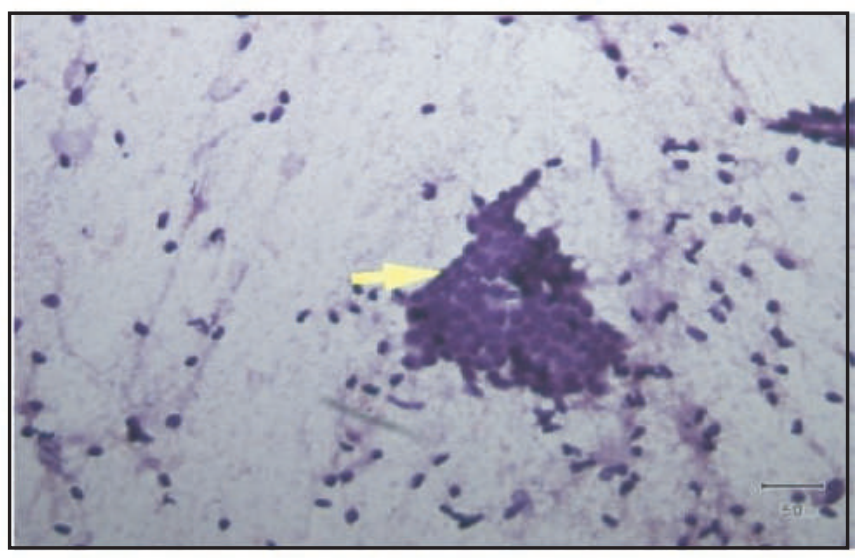

Figure 4 : Fibro adenoma 400 X (Pap stain) FNA smear.

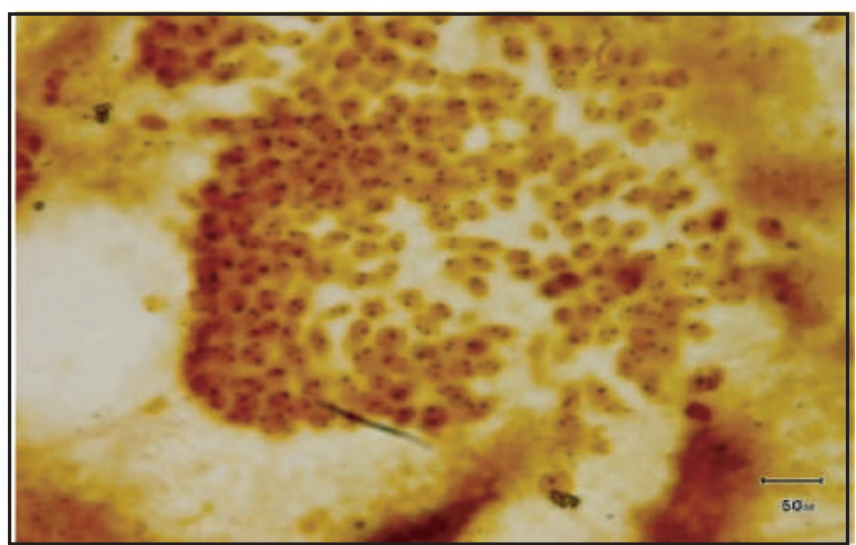

Figure 5 : Fibroadenoma 1000 X (AgNOR stain) FNA smear.

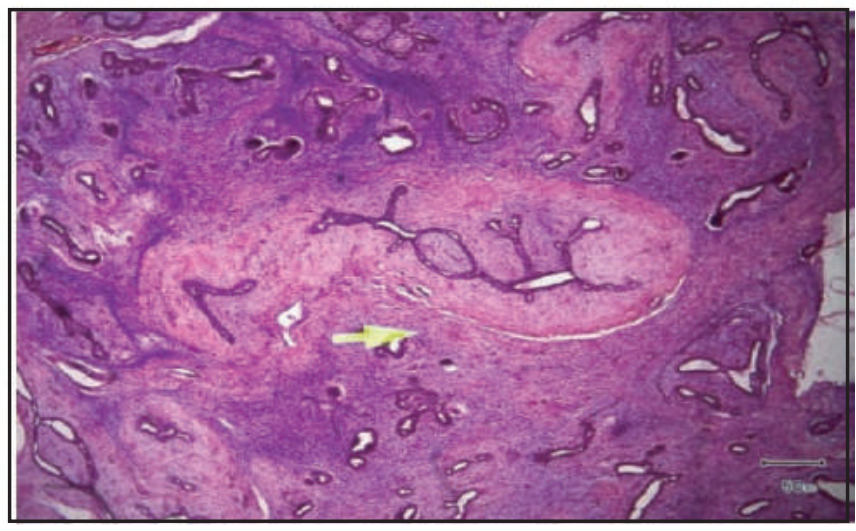

Figure 6 : Fibroadenoma 400 X (H \& E stain) Histopathology section. 


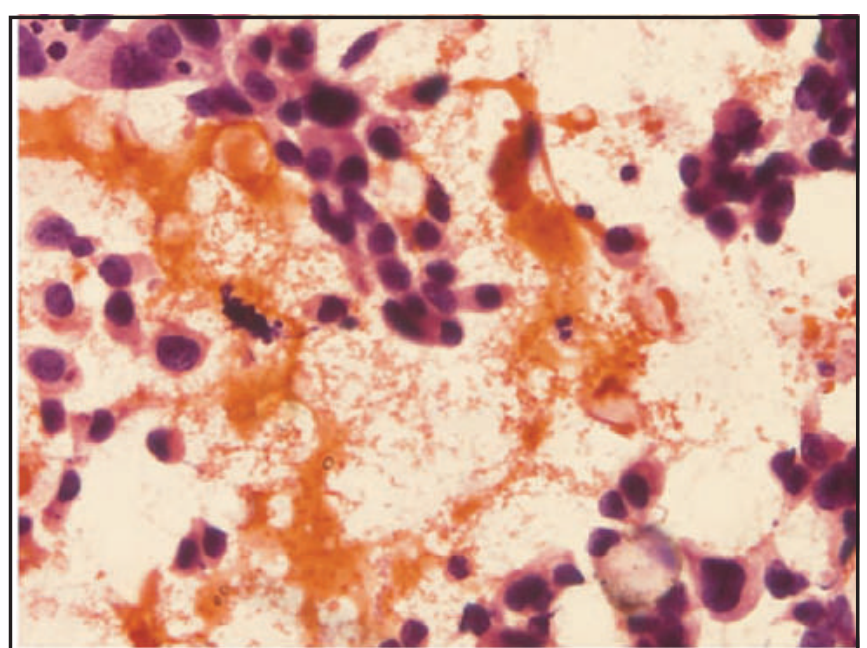

Figure 7 : Duct Cell Carcinoma 400 X (Pap stain) FNA smear.

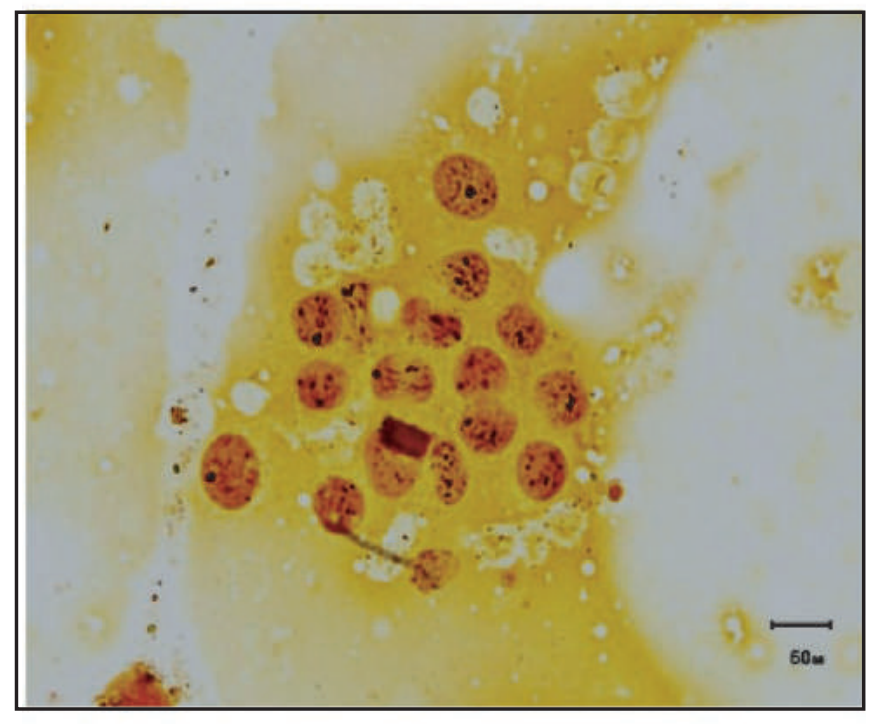

Figure 8 : Duct Cell Carcinoma 1000 X (AgNOR stain).

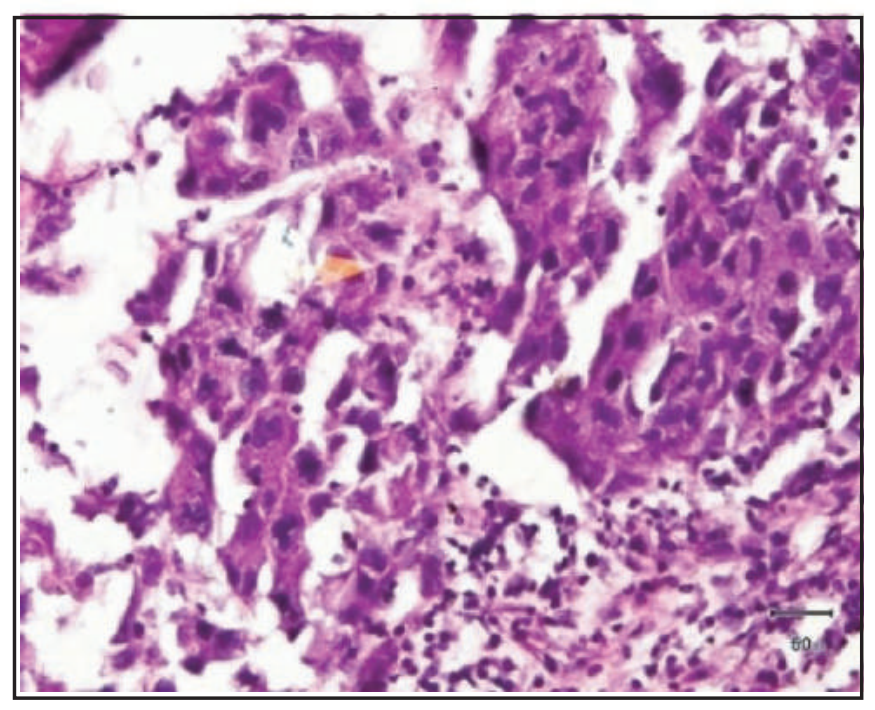

Figure 9 : Duct Cell Carcinoma 400 X (H \& E stain) Histopathology.

\section{RESULTS}

The age range of the 200 patients was $15-70$ years and mean age was 33.65 years.. The cases were divided into different age groups $(1=$ upto 20 years, $2=21-30$ years, $3=31-40$ years, $4=41-50$ years, $5=51-60$ years and $6=$ over 60 years.). The number $\&$ percentage of cases in different age groups The history of 200 patients, clinical findings, FNAC, AgNOR findings and histopathological findings were noted in a preformed data sheet. A total 51 malignant cases were found.Among the 200 patients by FNAC, 53 (26.5\%) cases were non-neoplastic benign, $89(44.5 \%)$ cases were benign neoplasm, $07(3.5 \%)$ cases were atypical ductal hyperplasia and $51(25.5 \%)$ cases were malignant lesion. Out of 53 nonneoplastic benign cases, 07 cases were inflammatory lesion, 28 cases were fibrocystic changes, and 18 cases were non-specific or inconclusive. Out of 89 benign neoplasms all were fibroadenoma and out of 51 malignant cases, all were duct cell carcinoma (Table $1 \& 2$ ).

Table 1: Distribution of breast diseases according to age group $(\mathrm{n}=200)$.

\begin{tabular}{lrrrrr} 
Age Range & \multicolumn{3}{c}{ FNAC Category } & Total \\
& $\begin{array}{c}\text { Non-neoplastic } \\
\text { benign }\end{array}$ & $\begin{array}{c}\text { Benign } \\
\text { neoplasm }\end{array}$ & $\begin{array}{c}\text { Atypical } \\
\text { ductal } \\
\text { hyperplasia }\end{array}$ & Malignant & \\
<20 yrs & 10 & 40 & 00 & $00(00.00 \%)$ & $50(25 \%)$ \\
$21-30$ yrs & 13 & 39 & 02 & $07(13.72 \%)$ & $61(30.5 \%)$ \\
$31-40$ yrs & 13 & 05 & 01 & $09(17.65 \%)$ & $28(14 \%)$ \\
$41-50$ yrs & 12 & 03 & 04 & $16(31.37 \%)$ & $35(17.5 \%)$ \\
$51-60$ yrs & 05 & 01 & 00 & $13(25.49 \%)$ & $19(9.5 \%)$ \\
$61-70$ yrs & 00 & 01 & 00 & $06(11.77 \%)$ & $07(3.5 \%)$ \\
Total & $53(26.5 \%)$ & $89(44.5 \%)$ & $07(3.5 \%)$ & $51(25.50 \%)$ & $200(100 \%)$
\end{tabular}

Table 2 : Frequency of breast diseases $(n=200)$.

\begin{tabular}{|c|c|c|c|}
\hline FNAC Impression & FNAC Diagnosis & \multicolumn{2}{|c|}{ Frequency \& percent } \\
\hline \multirow[t]{3}{*}{ Non-neoplastic benign } & Inflammatory & $07(3.5 \%)$ & \\
\hline & Fibrocystic Changes & $28(14 \%)$ & $53(26.5 \%)$ \\
\hline & Others & $18(9 \%)$ & \\
\hline Benign neoplasm & Fibroadenoma & $89(44.5 \%)$ & \\
\hline Atypical ductal hyperplasia & Atypical ductal hyperplasia & $7(3.5 \%)$ & \\
\hline Malignant & Duct cell carcinoma & $51(25.5 \%)$ & \\
\hline Total & & $200(100 \%)$ & \\
\hline
\end{tabular}

\section{AgNOR impression in FNA smears}

AgNOR analyses were done in all 200 cases of FNA smears. Out of 200 cases, 53 cases were non-neoplastic benign lesions, 89 cases were benign neoplasm, 07 cases were atypical ductal hyperplasia and 51 cases were malignant lesions. Overall mean mAgNOR were 3.00 ( $\mathrm{SD} \pm 2.14$ ), mean pAgNORwere 9.40 $(\mathrm{SD} \pm 11.50)$, mean $\mathrm{AgNOR}$ size were 0.66 ( $\mathrm{SD} \pm .87)$. Mean $\mathrm{mAgNOR}$ in case of non-neoplastic benign lesions were 1.52 $(\mathrm{SD} \pm 1.40)$, in benign neoplasm were $2.18(\mathrm{SD} \pm .91)$ and in malignant lesions were $5.64(\mathrm{SD} \pm 1.73)$. Mean $\mathrm{pAgNOR}$ in nonneoplastic benign lesions were 3.75 ( $\mathrm{SD} \pm 7.25)$, in benign neoplasm were $4.98(\mathrm{SD} \pm 3.68)$ and in malignant lesions were 21.47 ( $\mathrm{SD} \pm 13.99)$. Mean AgNOR size, in non-neoplastic benign 
lesions were $0.38(\mathrm{SD} \pm 0.90)$, in benign neoplasm were 0.47 $(\mathrm{SD} \pm 0.62)$ and in malignant lesions were $1.12(\mathrm{SD} \pm 0.86)$.

136 patients showed $<3$ range of $\mathrm{mAgNOR}$ and 63 patients showed $>3$ range of $\mathrm{mAgNOR}$. $141(70.5 \%)$ patients showed $<8 \%$ grading of pAgNOR and $59(29.5 \%)$ patient showed $>11 \%$ pAgNOR. AgNOR size grading showed $1(0.5 \%)$ cases $0+$, $173(86.5 \%)$ cases $1+, 4(02 \%)$ cases $2+$ and $22(11 \%)$ cases showed $3+$ with much over lapping between benign and malignant lesions.

All this findings are shown on table 3 ( $a, b$ and $c)$.

Table 3 : Frequency of different parameter of $\operatorname{AgNORs}(n=200)$.

\begin{tabular}{lccccr}
$\begin{array}{c}\text { 3(a)mAgNOR } \\
\text { m AgNOR range }\end{array}$ & $\begin{array}{c}\text { Non- } \\
\text { neoplastic } \\
\text { benign }\end{array}$ & $\begin{array}{c}\text { FNAC } \\
\text { Benign } \\
\text { neoplasm }\end{array}$ & $\begin{array}{c}\text { Atypical } \\
\text { ductal } \\
\text { hyperplasia }\end{array}$ & Malignant & Total \\
$1(<3)$ & 50 & 86 & 0 & 0 & 136 \\
$2(3)$ & 0 & 0 & 1 & 0 & 1 \\
$3(>3)$ & 3 & 3 & 6 & 51 & 63 \\
Total & 53 & 89 & 7 & 51 & 200 \\
\hline
\end{tabular}

\begin{tabular}{lcccrr}
$\begin{array}{c}\text { 3(b)pAgNOR } \\
\text { p AgNOR grading }\end{array}$ & $\begin{array}{c}\text { Non- } \\
\text { neoplastic } \\
\text { benign }\end{array}$ & $\begin{array}{c}\text { Benign } \\
\text { neoplasm }\end{array}$ & $\begin{array}{c}\text { PNAC } \\
\text { Atypical } \\
\text { ductal } \\
\text { hyperplasia }\end{array}$ & Malignant & rotal \\
$1(<8 \%)$ & 50 & 87 & 2 & 2 & 141 \\
$3(>11 \%)$ & 3 & 2 & 5 & 49 & 59 \\
Total & 53 & 89 & 7 & 51 & 200 \\
\hline
\end{tabular}

\section{3(c)AgNOR size grade}

\begin{tabular}{lcccrr}
$\begin{array}{l}\text { AgNOR size } \\
\text { grading }\end{array}$ & $\begin{array}{c}\text { Non- } \\
\text { neoplastic } \\
\text { benign }\end{array}$ & $\begin{array}{c}\text { FNAC } \\
\text { Benign } \\
\text { neoplasm }\end{array}$ & $\begin{array}{c}\text { Atypical } \\
\text { ductal } \\
\text { hyperplasia }\end{array}$ & Malignant & Total \\
\hline $0+$ & 0 & 0 & 0 & 1 & $1(0.5 \%)$ \\
$1+$ & 49 & 87 & 3 & 34 & $173(86.5)$ \\
$2+$ & 0 & 2 & 0 & 2 & $4(2 \%)$ \\
$3+$ & 4 & 0 & 4 & 14 & $22(11 \%)$ \\
Total & 53 & 89 & 7 & 51 & $200(100 \%)$
\end{tabular}

Among the 200 cases of breast lesions, biopsy and histopathology were done in 99 cases. Histopathological diagnoses showed $14(14.14 \%)$ non-neoplastic benign (Fibrocystic changes), 37 (37.37\%) were benign neoplasm. (36 Fibroadenoma and 1 Phylodestumour,which were diagnosed as fibroadenoma by FNAC) and 48 (48.49 \%) were malignant (Duct cell carcinoma). The results are shown in Table 4.
Table 4 : Distribution of histopathological findings ( $n=99)$.

\begin{tabular}{lcc} 
Histopathologic typing & Frequency & Percent \\
FCC & 14 & 14.14 \\
FA & 36 & 36.36 \\
Phylodestumor & 01 & 01.01 \\
Duct cell carcinoma & 48 & 48.49 \\
Total & 99 & 100.0 \\
\hline
\end{tabular}

FNAC results of histopathologically diagnosed 99 cases showed 13 non-neoplastic benign case, 42 were benign neoplasm (Fibroadenoma), 4 atypical ductal hyperplasia,and 40 cases were duct cell carcinoma. Out of 40 FNAC malignant cases, histopathologically all were proved malignant. Out of 42 benign cases, 1 was found malignant. 4 atypical ductal hyperplasia were also diagnosed as malignant histopathologically. True positive cases are 40, True negative cases are 36, false positive are nil (0), and false negative is 01 . (Non neoplstic benign and atypical ductal hyperplasia are excluded from the statistics). The sensitivity is $97.56 \%$, specificity is $100 \%$, positive predictive value is $100 \%$, Negative predictive value is $97.3 \%$, and accuracy is $98.7 \%$. The association between FNAC and histopathological diagnoses are shown in the Table 5 ( $a$ and $b$ ).

Table 5(a): Association between FNAC and histopathological findings $(\mathrm{n}=99)$.

\begin{tabular}{|c|c|c|c|c|c|}
\hline \multirow[t]{2}{*}{ FNAC Category } & \multicolumn{3}{|c|}{ Histopathology } & \multirow[b]{2}{*}{$\begin{array}{l}\text { Not } \\
\text { done }\end{array}$} & \multirow[b]{2}{*}{ Total } \\
\hline & $\begin{array}{c}\text { Non- } \\
\text { neoplastic } \\
\text { Benign }\end{array}$ & $\begin{array}{l}\text { benign } \\
\text { Neoplasm }\end{array}$ & Malignant & & \\
\hline Non-neoplastic benign & 9 & 1 & 3 & 40 & 53 \\
\hline Benign neoplasm & 5 & 36 & 1 & 47 & 89 \\
\hline $\mathrm{ADH}$ & 0 & 0 & 4 & 3 & 7 \\
\hline Malignant & 0 & 0 & 40 & 11 & 51 \\
\hline Total & 14 & 37 & 48 & 101 & 200 \\
\hline
\end{tabular}

$\chi^{2}=161.83, p<0001$, Highly significant ( Chi-Square test)

Table V(b): Statistical evaluation of FNAC in the diagnosis of Breast lesion ( $\mathrm{n}=99)$.

\begin{tabular}{lr} 
Validity test ( Chi-square test) & Result \\
Sensitivity & $97.56 \%$ \\
Specificity & $100 \%$ \\
Positive predictive value & $100 \%$ \\
Negative predictive value & $97.3 \%$ \\
Accuracy & $98.7 \%$ \\
\hline
\end{tabular}

AgNOR impression was analysed in 99 histopathologically confirmed cases. The results showed benign impression in 50 cases and malignant impression in 48 cases. 01 histopathologically malignant case was impressed as benign by AgNOR and 01 as suspicious which was included as malignant 
by AgNOR impression. 2 histopathologically benign cases showed higher proliferative activities and counted as malignant.True positive cases are 46 , True negative 49 , False positive is 02 and false negative is 01 . The sensitivity is 97.87\%, specificity $96.07 \%$, PPV 95.83\%, NPV 98\%, Oveall accuracy is $96.93 \%$. The association between AgNOR and histopathologic diagnoses are shown in the Table 6 (a).

Table 6 (a) : Association between AgNOR and histopathological diagnosis $(n=99)$.

\begin{tabular}{lrccc} 
AgNOR Impression & \multicolumn{4}{c}{ histopathological Diagnosis } \\
& 14 & 35 & 1 & 50 \\
Nenign & 0 & 0 & 1 & 01 \\
Suspicious/Atypical & 0 & 02 & 46 & 48 \\
Malignant & 14 & 37 & 48 & 99 \\
Total & & Benign & Malignant & Total \\
\hline
\end{tabular}

$\chi^{2}=134.29 ; \mathrm{p}<0001 ;$ Highly significant

Table 6 (b) : Statistical evaluation of AgNOR impression on FNA smears in the diagnosis of breast lesion $(n=99)$.

$\begin{array}{lr}\text { Validity test ( Chi-square test) } & \text { Result } \\ \text { Sensitivity } & 97.87 \% \\ \text { Specificity } & 96.07 \% \\ \text { Positive predictive value } & 95.83 \% \\ \text { Negative predictive value } & 98 \% \\ \text { Accuracy } & 96.93 \%\end{array}$

\section{DISCUSSION}

FNAC has gained popularity as a procedure for diagnosis of breast lump in all over the world including Bangladesh, because of the simplicity of the procedure, good tolerance by the patients, rapidity, cost effectiveness and safety. However, from time to time, cytological picture may be equivocal or inconclusive. Sometimes, the clinical use of FNAC has been questioned because of the variability in results reported. Addition of another simple procedure AgNORs analysis on FNA smears simultaneously will streng then the accuracy of FNAC of breast in differentiating reactive, benign and malignant tumours of the breast.

Papanicolau and and AgNOR analyses done on all FNA smears of 200 breast lesions.Among them, biopsy and histopathology were done in 99 cases and the findings were compared to respective FNA and AgNOR findings separately and statistically evaluated.
Out of 40 FNAC malignant cases, histopathologically all were proved malignant. Out of 42 benign cases, 1 was found malignant. 4 atypical ductal hyperplasia were also diagnosed as malignant histopathologically. 01 fibroadenoma diagnosed by FNAC was found Phyllodes tumour by histopathology. True positive cases are 40, True negative cases are 36 , false positive are nil (0), and false negative is 01 . (Non neoplstic benign and atypical ductal hyperplasia are excluded from the statistics).The sensitivity is $97.56 \%$, specificity is $100 \%$, positive predictive value is $100 \%$, Negative predictive value is $97.3 \%$, and accuracy is $98.7 \%$.

There are limited studies regarding AgNOR analysis of breast lesions, most of which are based on mAgNOR count (Monoparametric) only. Ansari et al observed mean mAgNOR, $2.96(\mathrm{SD} \pm 0.72$ ) and pAgNOR 14.1 in benign neoplasmand mean mAgNOR $4.0(\mathrm{SD} \pm 1.42)$,pAgNOR $36.6 \%$ in malignant neoplasm, which are similar to the findings of present study ${ }^{13}$. Ahmed et al showed mean mAgNOR in benign neoplasm was 1.26 and in malignant neoplasm was 2.57. Chughtai et al in their study observed mean mAgNOR in benign neoplasm $6.87(\mathrm{SD}=0.92)$ and in malignant cases was $18.51(\mathrm{SD}=2.90)^{1,11}$. The findings of these two studies also support the findings of present study.

Histopathological diagnoses showed 14 (14.14 \%) nonneoplastic benign case, 37(37.38\%) was benign neoplasm and $48(48.48 \%)$ cases were malignant. All the non-neoplastic benign cases were fibro-cystic diseases. Out of 37 benign neoplasms were 36 were fibro-adenoma and 01 was phylodestumour (Which was diagnosed as fibroadenoma by FNAC) and malignant neoplasm were invasive Duct Cell Carcinoma (NOS).

The results of AgNOR analysis showed benign impression in 51 cases and malignant impression in 46 cases. 01 histopathologically malignant case was impressed as benign by AgNOR and 01 as suspicious. 2 histopathologically benign cases were impressed as malignant by AgNOR analysis. True positive cases are 46 , True negative are 49 , false positive are 02 and false negative are 02 .The sensitivity is $97.87 \%$,specificity $96.07 \%$, PPV 95.83\%, NPV 98\% and overall accuracy is $96.93 \%$.

\section{CONCLUSION}

Qualitative and quantitative analysis of AgNORs on FNA smear can strengthen the efficacy of FNAC of palpable breast lump in differentiating reactive, benign and malignant tumours of the breast.

\section{DISCLOSURE}

All the authors declared no competing interest. 


\section{REFERENCES}

1. Ahmed G H, Al-Adhraei M A and Ashankyty I M. Assosiation between AgNORs and Immunohistochemical Expression of ER, PR, HER2/Neu, and p53 in Breast Carcinoma. Pathology Research International, 2011, Accepted on 26th August 2011.

2. Ibrahim E D and Khaled S. Detection of Nucleolar Organizer Regions (NORs) as an Independent proliferative Tumour Index. Australian Journal of Basic and Applied Sciences. 2011;5(11):2170-2171.

3. Cecilia M. and Fenogolia, P. Selection of appropriate cellular and molecular biologic diagnostic tests in evaluation of cancer. CANCER supplement. 1992;69(6):1607-1632.

4. Yamaguchi S. Relationship between the responses to simultaneous Double staining for ki-67 and AgNOR and the Clinicopathological features of non-small cell pulmonary carcinoma, Acta Medica Nagasakiensia. 1994;39(4):147-152.

5. Manu S C V, Rajaram T and Rai R. Value of Silver Binding Nucleolar Organiser Regions (AgNOR) in squamous cell carcinomas of upper aero-digestive Tract. MJAFI. 2006; 62(2):123-128.

6. Meenu G, Uma S, Mahapatra Q S, Gehlot S, Gupta V and Sen R. Role of argyrophilic nucleolar organizer region staining in identification of malignant cells in effusion. Journal of cytology. 2011;28(4):191-195.

7. Hasnan J and Gita J. Nucleolar organizer regions distribution in fine needle aspiration cytological smears from breast lesions. Malayasian J Pathol. 1996;18(1):35-41

8. Shazia N I, Chaudhry N A and Khan S A. AgNOR proliferative Index in Malignant pleural and peritoneal effusions. International Journal of Pathology. 2005;3(2): 86-90.

9. Hatano and Kazuhiko. Significance of AgNOR ratio as a prognostic factor of breast cancer, Acta Medica Nagasakiensia. 1994;39(1-3):179-183.

10. Hideo J, Nanashima A, Yano H, Matsumoto M, Yasutake T and Nagayasu T. Clinical significance in double staining of MIB-1 and AgNORs in primary breast carcinoma. Anticancer Research. 2005;25:3957-3962.

11. Chugtai N M, Javed Z and Asif M J. Comparative Study of Silver stained Nucleolar Organizer Regions (AgNOR) between Fine Needle Aspiration Cytology (FNAC) and Histology of Palpable Breast Lumps. Pakistan Journal of Medical Health Sciences. 2008;2(6):1-6.

12. Derenzini M, Ceccarelli C, Santini D, Taffurelli and Trere. D. The prognostic value of the AgNOR parameter in human breast cancer depends on the $\mathrm{pRb}$ and $\mathrm{p} 53$ status, J Clinpathol. 2004;57:755-761.

13. Ansari H A, Mehdi G, Maheshwari V. and Siddiqi S A. Evaluation of AgNOR Scores in aspiration cytology smears of breast tumours. Journal of Cytology. 2008;25(3): 100-104

14. Odjel Z C. Needle aspiration cytology of the breast: Current perspective on the role in diagnosis and management. Acta Med Croatica . 2008; 62(4):391-401.

15. Khatun H, Tareak A N, Enam S, Hussain M and Begum M. Correlation of fine needle aspiration cytology and its histopathology in diagnosis of breast lumps. Bangladesh Medical Research Council Bulletin. 2012; 28(2):77-81.

16. Nagao T, Bando Y, Sasa M. et al. False- positives in Fine-Needle Aspiration cytology of breast disease can be Reduced with p63 Immunostaining: A preliminary Report. Anticancer Research. 2006;26:4373-4378.

17. Mendoza P, Lacambra M, Tan P H and Tse G.M. Fine Needle Aspiration cytology of the breast: The nonmalignant categories. Pathology Research International. 2011; Article ID 547580.

18. Mark J B, Wilson G D and Makris. A Measuring proliferation in breast cancer: Practicalities and applications. Breast cancer research. 2006;8(6):1-11.

19. Hossain M I, Hassan Q M, Bhattachrjee P, Ahmed S U M. and Rahman Z. Role of multiparameter analysis of AgNORs in FNA smears of thyroid swellings in differentiating benign and malignant lesions. Pathology Research International. 2012. Article ID 908106.

20. Khan S A, Chaudrhy N A, Khalid A W, Aktar G N and Ibne-Rasa S N. Pattern of argyrophilic nucleolar organizer regions in pleural and peritoneal effusion. J Coll Physicians Surg, Pak. 2006;16:412-415. 